\title{
The Effectiveness of Blackboard System, Uses and Limitations in Information Management
}

\author{
Jamilah A. Alokluk \\ School of Arts and Humanities, Taibah University, Madinah, KSA \\ Email: jokluk@taibahu.edu.sa
}

How to cite this paper: Alokluk, J.A. (2018) The Effectiveness of Blackboard System, Uses and Limitations in Information Management. Intelligent Information Management, 10, 133-149. https://doi.org/10.4236/iim.2018.106012

Received: March 23, 2018

Accepted: November 27, 2018

Published: November 30, 2018

Copyright $\odot 2018$ by author and Scientific Research Publishing Inc. This work is licensed under the Creative Commons Attribution International License (CC BY 4.0).

http://creativecommons.org/licenses/by/4.0/

(c) (i) Open Access

\begin{abstract}
This paper presents a review of the literature on the effectiveness of Blackboard system, its uses and limitations in information management and highlights the ongoing debate of it. A critical evaluation of Blackboard system literature reveals a good number of academic views, studies, theories, models and experiences regarding the virtual learning environment. The extant literature shows that the world of information management is always in flux as it is being impacted on by the learning technology such as blackboard system. Blackboard system now has a recognised presence in the information management of the education system. Now the question is: how effective is this Blackboard system? The article will explore, in part, how blackboard is designed as suitable learning models in terms of learner cognitive engagement and constructivist perspective, resulting in the effective Blackboard system. It will further cover to review the effectiveness of Blackboard as an aid to pedagogy. Finally, the article will also present a comparison between Blackboard and other LMS such as Moodle to explore the effectiveness and limitations of the Blackboard for better academic information management.
\end{abstract}

\section{Keywords}

Blackboard, Virtual Learning Environment (VLE), Pedagogy, Learning Management System (LMS), Information Management

\section{Introduction}

The rapid development in information technology has revolutionised the practices of teaching and learning in educational setting. Numerous studies reveal that the quantity and quality of e-learning systems such as "Blackboard" in higher education have increased significantly over the years. Students and teachers access this virtual learning environment together to make effective in- 
teraction with one another by way of chat, podcasts, discussion boards, and file sharing. In fact, the adoption of Blackboard has revolutionised the traditional teaching system, resulting in the effective educational information management. Researchers argue that this type of management of information results in the utilisation of codified knowledge that produces formal representations of information entities, allowing process automation, decision-making and information retrieval. Blackboard goes a long way in converting the tacit knowledge to explicit or codified knowledge that eliminates the factors of loss of knowledge owing to memory limitations. Also, the use of e-learning systems such as "Blackboard" helps reduce the costs of knowledge reproduction, leading to effective knowledge management. Although e-learning offers advantages for teachers, learners and institutions, it raises basic questions about the learning process [1]. Thus, questions whether e-learning is simply a supplementary help mechanism for principal learning methods [2]. Presently, many of these e-learning technologies tend to focus on the delivery of mechanical information [3] [4], that is termed as digital myopia [5], rather than on innovative pedagogic approach to learning [6]. Given this context, examining the effectiveness of blackboard system, uses and limitations in information management has become all the more important.

\section{Background}

Virtual learning environments include both small single-purpose tools (e.g., GoogleDocs and wikispaces) and collaborative virtual learning environments (e.g., Blackboard, Moodle, Schoology, Edmodo) [7]. These tools facilitate synchronous and asynchronous e-learning. The present study purports to explore the effectiveness of e-learning environment, i.e. Blackboard that is considered to make effective contributions to quality teaching and learning as well as find out those aspects that might appear as barriers to quality teaching and learning. Effective implementation of Blackboard must address a number of barriers, including institutional culture, pedagogical and technical support, teacher's familiarity with technology and pedagogical content knowledge, students' technical knowledge, and resources [7].

According to Olson \& Bruner [8] (p. 150), "The acquisition of knowledge as the primary goal of education can be seriously questioned". There are models of education in the information age, such as Blackboard assesses students' existing knowledge level, shares course materials database, supports collaboration (teacher-student, student-student, teacher-teacher) and evaluates learner goals and performance in order to maximise the effectiveness of the institutions. It is in this context that Herrington [5] (p. 4) commented, “..., in the age of course management software (such as WebCT and Blackboard), why universities might think they are in the information industry". Information industry focuses on the four Gs: "Firms in this industry generate, gather, and group information, and then give (sell) information to other firms" [9] (p. 2). Building on Miller [9], 
Herrington [5] (p. 5) appropriately observed:

- Teachers generate the content that they decide is appropriate for the students to know;

- They gather appropriate and specific resources that are relevant to the content area;

- They group the information into weekly portions or modules; and

- They give the information to the students.

Literature survey reveals that the above information management approach has got limitations; as they do not engage the learners cognitively and in constructivist approach [5] [10] [11] [12]. Thus, most e-learning models do not focus on rich interactive experiences. Rather, they emphasise on the model of easily digested packets of information, evaluated by stand-alone tests in an isolationist way [13]. Therefore, the effectiveness of blackboard rests on more constructivist, interactive online learning environments [14] [15]; and the ability to design learning activities which can cognitively engage the learner, and cause them to think about the course materials that are uploaded, in terms of meaning, relevance, application and contexts [12].

It is true that technology has an important role to play in the development and expansion of online education. In order to address the afore-mentioned limitations, i.e. 'digital myopia' [5], a synergy among learner, task and technology needs to be created. This synergy can be created by designing learner-centric technology with meta-cognitive tools that are based on learning behaviour or providing simulations of complex system that learners can benefit from [16]. Appropriate technology can enhance the effectiveness of the Blackboard by offering the relevant type of interactions, leading to the promotion of metacognition and self-regulated learning [17]. Research shows that properly designed technology-rich learning enhances learner self-regulation and causes positive learning behaviour modification [18] [19]. Therefore, "the design of the [Blackboard] should take into account both the cognitive and affective domain to enhance self-regulation" [15] [20] [21]. Boekaerts [21] is of the view that the e-learning environment in Blackboard should provide technology-rich supports for students to learn how to: "select, combine, coordinate their cognitive strategies in connection to the new knowledge, and prompted to reflect on their strategy use, extending their metacognitive knowledge with strategy and capacity beliefs" (cited in Y. Vovidesa [15] (p 67). Consequently, limitations in information management can be addressed by quality learning that is facilitated through more constructivist, interactive online learning environments [14] [15].

\section{The Utilisation of Blackboard}

Blackboard is a learning management system (LMS), which is used not only as a repository of information, i.e. course materials and course information but also used as a tool for communication through emails, announcements, discussion boards and podcasts etc. The utilisation of Blackboard solely depends on the ef- 
ficiency of the users. Users need to be able to utilise this educational technology competently to facilitate the learning. Otherwise, it will be "one step ahead for the technology, two steps back for the pedagogy" [10] [11] (p 239). If teachers use Blackboard incompetently, then Blackboard becomes less useful to students. Proper utilisation of Blackboard depends on the ability of the teachers to integrate the technology with student-centered learning [7]. According to a study, "only 23 percent of teachers surveyed feel prepared to integrate technology into their instruction" [7], (p. 7). Also, it is true that students and teachers need to have the motivation to become expert users of e-learning. If not, it can limit their use of innovative pedagogies [22]. Thus, the utilisation of Blackboard depends on assessment of current realities, i.e. addressing the constructivist pedagogy. Current realities reflect that because of the educational technology revolution, Blackboard can deliver personalised, learner-focused contents and activities. It also promotes interactivity, and engaged learning with immediate feedback [22]. Blackboard is used by more than $70 \%$ of the U.S. colleges and universities [22].

\subsection{Utilisation of Blackboard by Faculty}

Teachers play a fundamental role in ensuring that Blackboard promotes student-centred learning. According to Carvendale [23] (p. 26), "Professors at many universities say that course-management software helps them organize their courses better and brings new levels of interaction both among students and between students and professors." However, another study conducted by Anderson [24] reported Blackboard system to be perceived as inflexible by faculty, and difficult to use by students. This can happen because of Blackboard's limitations and lack of technical flexibility. Another study was conducted at University of Wisconsin System (UWS) that explored how faculty members used the Blackboard, and what features were regularly used [25]. The study also investigated the circumstances that would induce faculty members' greater use.

The key findings of the UWS study are as follows [26]:

1) Poor LMS uptake rates because faculty feared loss of control of instruction and believed that the inflexibility of LMS procedures would undermine pedagogy. There was no reported evidence that showed that the LMS improved pedagogy.

2) Most faculty ( 80 percent of those surveyed) limited their use of LMS only to content presentation tools. The faculty reported limited use of LMS interactive parts, with strong focus on the 'static' tools (SafeAssign, surveys, quizzes and tests).

3) Faculty members' adoption of LMS had less to do with pedagogy and more to do with class management.

4) Faculty adoption of LMS is mostly due to persuasion of departmental chairs, provosts and deans.

5) The UWS study also found that training was crucial. Most faculty expressed 
that their use of LMS would grow if the software were easy to use and the training were more available.

This finding at serial number (d) reflects one of the observations made by Lane [27] (p. 5), where he advanced, "more instructors embrace online teaching because they are pressured to", not because they want to. Consequently, teachers are more prone to use administrative and static tools rather than uncover pedagogic perspectives. Continued use of Blackboard does not necessarily lead to more creative use of pedagogy. It is found that even faculty members with long experience make requests for help that tend to focus on simple technological issues rather than how their teaching and learning goals can be achieved through Blackboard. One study indicated that even experienced teachers use Blackboard for mere grade administration, email and presenting static content [27].

A study conducted by Blin and Munro [28] concluded that despite widespread usage of Blackboard system at Dublin City University, nominal change in the arrangement and composition of teaching and learning had occurred. Much of the Blackboard system use of the faculty was concentrated on administrative and dissemination purposes. Only static, content-based resources were the main focus of the faculty that were added to the Blackboard. They attributed this situation to lecturers' shortage of technical skills. They found that training would be needed to address effective use of the Blackboard. On this issue, their study seemed to agree with the University of Wisconsin System study, which also highlighted the importance of training. Literature survey also reveals that many new faculty members are web novices. They do not know how to use the tools and features of Blackboard as they do not have profound understanding about effective use of e-learning technology [26]. Therefore, due to the complexity in predicting the reason for quality blackboard outcomes, researchers point out that it is because of the way technology is used, rather than the effect and impact of technology itself [29]. Al-Busaidi [30] is of the view that if faculty members do not have well-developed sense of the applications or tools within the blackboard system, most faculty members will stop using it. Thus, to improve the way technology is used, training is important in terms of enhancing the effective utilisation of Blackboard.

However, in the context of LMS, Blackboard has become a "glorified toolkit" to meet the demands [31] as "Blackboard is a multimedia curriculum-driven learning system that provides instructors with control and flexibility" [32]. A survey conducted on this issue [33] revealed that seventy seven percent of participants expressed positive views about discussion boards and emails that increased interaction and collaboration amongst users [34]. Also, Wheeler and Jarboe [35] observed, the increased faculty use of technology tools in classroom further induces them to use these tools more comprehensively. A study by Eldridge [36] reveals that majority of the faculty of the University of Kentucky use syllabus component of the Blackboard. Other popular components included "Announcements" and "Full Grade Center". 
In New Zealand, "Blackboard" was introduced in tertiary education in 1990s that facilitated e-learning processes, leading to the elimination of the difficulties of course delivery previously done through the postal services. Since then, Blackboard has been playing pioneering role in education there as faculty feedback is positive [31]. According to Nanayakkara [37], many educational institutions now use online teaching tools such as 'Blackboard' as their LMS. In particular, the study conducted in a New Zealand Polytechnic by Nanayakkara [37] revealed that peer pressure and influence would strongly contribute to faculty decision to adopt Blackboard LMS (70\% of respondents). Moreover, findings suggest that the majority of the faculty consider that Blackboard positively contributes to quality of learning and also enhances the traditional teaching with improved flexibility [37]. Faculty members use Blackboard as it is easy to use and use tools such as course delivery, classroom activities and communication [31]. The email communication tool is also a popular tool. Her research also shows that Blackboard is more used for administrative purposes and less used for pedagogical purposes. However, there should be a good balance between them. The balance can be maintained by following the seven online teaching principles.

Faculty members' utilisation of the Blackboard Learning System should aim at achieving seven online teaching principles [38]:

Principle 1: Good practice encourages student-faculty contact, Instructors should provide clear guidelines for interaction with students;

Principle 2: Good practice encourages cooperation among students, Well-designed discussion assignments facilitate meaningful cooperation among students;

Principle 3: Good practice encourages active learning, students should present course projects;

Principle 4: Good practice gives prompt feedback, Instructors need to provide two types of feedback: information feedback and acknowledgment feedback;

Principle 5: Good practice emphasizes time on task, online courses need deadlines;

Principle 6: Good practice communicates high expectations, challenging tasks, sample cases, and praise for quality work communicate high expectations;

Principle 7: Good practice respects diverse talents and ways of learning, allowing students to choose project topics incorporates diverse views into online courses.

Thus, the seven principles contribute to effective learning outcomes. However, excepting the seven principles, it is evident from the above discussion that the emphasis is more on the functional and administrative features of Blackboard and far less on the pedagogy and interactive learning. Also, the features of Blackboard are not properly designed to enable teachers to focus on the pedagogical perspectives. Moreover, faculty members are concerned about unknown 
changes. Technology administrators usually do not communicate with the faculty about why decisions are made to adopt or stop specific blackboard tools. Faculty, thus often feel subject to capricious whims of technology [25]. Consequently, faculty feel demotivated to use the pedagogical perspectives of the Blackboard. Rather, they prefer to use the static tools.

\subsection{Utilisation of Blackboard by Students}

The effective utilisation of the Blackboard learning system depends on user readiness, organisational culture and system adoption as the literature supports. However, Lee and Choi [39] suggest that environmental factors such as non-availability of financial and social support from family and friends, causes difficulties to student utilisation of online courses. Also, employment acts as a significant barrier for students engaging more in their online studies [40]. Insufficient experience with online learning and other work commitments leads to poor student utilisation of online learning environment. Morgan's [25] UWS study revealed that students had insufficient skills to use online learning features without training.

Various reports suggest that student retention is positively contingent on innovative and engaging online activities and course design [41]. Thus, student engagement with Blackboard is a key concern for educators as it has been positively associated with motivation and student grade and educational outcomes. In a study conducted at Central Missouri State University to assess the quality of web-based courses and students' utilisation [42], the results revealed that students with higher grades accessed the online activities more than students with poorer grade.

In a traditional classroom setting, a common disadvantage to face-to-face instruction is the cultural differences between the faculty and the student. These differences can crop up as there are individuals speaking different languages. However, in blended learning the Blackboard environment offers a number of online educational opportunities and advantages for students. First utilisation is when a student gets feedback online to his/her queries from the faculty through emails, discussion board it encourages a deeper level of thinking where the emphasis is on the written word [43]. Also, in a Blackboard learning environment "students are:

1) Able to write while discuss;

2) Able to revise the class discussions note at anytime;

3) Able to retrieve discussions softcopy at anytime;

4) Able to add on or delete any part of the discussion at anytime;

5) Able to cut and paste any materials from other resources;

6) Able to edit and reorganise teaching materials at anytime;

7) Not constrained by study location" [44], (p. 63).

The above 7 utilisation of Blackboard finds match with four different approaches to interaction within e-learning. They are: 1) same time, same place 2) 
different time, same place, 3) same time, different place, and 4) different time, different place.

According to Bradford et al. [22], Blackboard Learning System meets the student learning needs in a positive way in terms of retrieving their course materials including assignments, lecture notes, slides, Internet hyperlinks, and audio/visual aid. Duke University conducted a feedback survey in 2004 where students were provided with a list of 10 functions of Blackboard and requested to select up to three functions that they used the most. The first option for $85 \%$ of students was "easy access to course materials and readings [22] [45].

A research applied the Technology Acceptance Model (TAM) [46] to the academic setting to measure student utilisation of Blackboard in terms of usage, usefulness, and ease of use. Results suggest that students found that "the Blackboard elements which are associated with Course Content (Course Documents, Lectures, Student Tools, Announcements, and Quizzes) are used more often and are seen as more useful than those items that provide Course Support and communication (Discussion Board, External Web Sites, Faculty Information, and E-Mail)" [47] [48]. Other researchers are [49] also of the view that usefulness and perceived ease of use represent beliefs finally leading to actual utilisation of information technology. In another study, it was revealed that learning activities and instructional strategies play a key role in teaching the necessary skills that in turn, encourage students to positively utilise the online learning. Thus, teachers have a role to play in the greater utilisation of Blackboard by the students.

A survey conducted [50] for the purpose of evaluating the usability of blackboard suggested that students' satisfaction was found to be strongly linked with the convenience and flexibility in the use of web-based tools. Accessing Blackboard anytime, anywhere and different learning tools that are required for their different learning styles were also found to be highly significant to students.

The findings of a researchby Al-Hadrami [42] reveal that, 'prior performance' and 'student attitudes toward web-based learning' are the most significant factors affecting student interaction and utilisation. Furthermore, environmental factors, such as student participation in web-based courses and student perceptions on instructors' instructions are found to have a bearing on student interaction.

In short, it can be said that the more students use the internet, the more they interact with the Blackboard and the more experienced they become. The interaction with the Blackboard enhances student utilisation. In short, students who interact with their peers via Blackboard tend to use it more often than those who didn't.

\section{Level of Effectiveness of the Blackboard System}

One of the determinants for evaluation of usefulness is effectiveness. Effectiveness is how users perceive the course tool as vital to them in terms of learn- 
ing-teaching activities that is also called Perceived Usefulness (PU). Venkatesh (1999) identified that PU relates to two factors: effectiveness and importance. The research findings indicated the effectiveness (PU) of the Blackboard in the following manner:

- Using Blackboard enables me to accomplish tasks quickly;

- Blackboard makes it easier for me to do teaching related tasks;

- I find Blackboard useful.

'Level of effectiveness' represents factors such as course delivery, students' benefits, functionality, technical difficulties [31]. Level of effectiveness is dependent on usage of course tools. Her research findings suggest that high frequent use or low frequent use of course tools is conditioned to a certain extent by the effectiveness of course tools. Hence, the observation of that '[U]sefulness' of a system has a positive influence on user's intended usage has been found valid in this research by Missula [31]. A further study [51] reveals what the university teachers reflect on learning through online discussion board: a. providing time and access:

a) Engaging learners;

b) Fostering a community of learners, and

c) Enabling higher-order cognition and learning.

All it boils down to the fact that university teachers consider the adoption of online discussion as a strategy to engage learners from constructivist perspectives, pointing to the higher order usefulness of the LMS. Constructivism is a learner-centred and teacher-directed theory that involves shifts between periods of teacher presentation ... and periods ... when students engage ..." [52] [53].

According to other researchers [54], blackboard adds value to e-learning system in terms of saving time, effort and money for both faculty and students. Furthermore, web 2.0 applications (a popular method of e-collaborative learning within the blackboard system) have become very popular because of its ability to promote knowledge and practical skills. Several tools of e-collaborative learning within the blackboard are wiki, panel discussions and virtual classrooms.

Wiki is an extensive database that allows the exchange of knowledge, leading to enhanced collaborative learning process [55]. Scholars [56] refer to Wiki as contributing to effectiveness of the Blackboard. In Mathematics classes, it allows collaborative content creation.

Panel discussions, another important feature of Blackboard, is an effective asynchronous collaborative discussion, where learners can express their opinions about any topic that starts conversation threads, which other course members can reply. Especially, it is effective for shy students who can express more freely when responding to discussions. A research conducted by Alzahrani and Aljraiwi [43] suggests that panel discussions can be used in simulating discussions taking places in the face-to-face traditional classrooms. Blackboard effectiveness can be enhanced by panel discussions by following usage:

- Using it as a forum for online discussions and interaction among Partici- 
pants.

- Using it as a place for interaction and exchange of ideas.

- Using it as a format for asking questions about homework and content of the academic courses.

- Using it as a discussion-record that can be revisited by participants.

Virtual classroom provides communicative environment in Blackboard that includes a synchronous chat room for interactive communications where faculty can give online lectures. It also allows for the recording of lectures in the blackboard system that can be accessed by students who miss the classes. Thus, it overcomes the obstacles of time and place [43].

Based on the above discussion, it is clear that the effectiveness of any e-learning management system, i.e., Blackboard, is reliant on user acceptance, usage and satisfaction. Learners' adoption and use is mandatory for effective Blackboard system. Measuring user acceptance and satisfaction is a basic element in managing e-learning initiatives [57].

\section{Limitation of Blackboard}

A study conducted [58] at the Park University, USA finds that the only specific problem with the Blackboard software platform is in the writing of mathematical equations. In order to solve this problem, Blackboard Collaborate offered various alternatives. However, it could not solve this problem completely. Faculty had to resort to innovative ways to express mathematical equations. The objectives of lectures, be it traditional classroom-based or LMS-based, is to provide the students with some skills. Psychomotor skills are those that require a complex combination of physical movement and psychological process, "such as learning how to drive a golf ball. These skills are difficult to teach in a Blackboard lesson, as they require an environment with coaching and detailed feedback" [58] (p. 2).

A research conducted at the UWS reveals that Blackboard is difficult to use. The findings of the research also found Blackboard system "time-consuming and inflexible" [25] (p. 3). Blackboard tools can be expensive. Other scholars [59] suggest that security and cost are two of the biggest limitations within an LMS. According to the American Council on Education, "costs associated with higher educational telecommunications ... be $\$ 7$ billion dollars, a 35 percent increase from the prior year" [25] (p. 5). Thus, cost has become an issue as educational institutes have to procure the dedicated software, hardware and pay the subscription license and hire additional staff to maintain the Blackboard. As Nayak and Suesaowaluk [60] suggest, “... startup costs, including hardware, software, staffing, and training, can be very expensive" (p. 22-23). Security is also asource of limitation because the "drawbacks pertain to the quality of learning in an eLearning environment which is sometimes sacrificed since there is a high security risk in the system" (p. 22-23). 


\section{Comparative Usability of Blackboard and Moodle}

There are almost 200 LMSs [42]. However, this article is going to compare the two most famous LMSs such as Blackboard and Moodle. Blackboard and Moodle provide effective virtual learning environment [48] [61]. Currently, the major contender in this market space is Blackboard that has thousands of deployments over 60 countries and is available in 8 major languages [62]. Concurrently, the most popular open source system is Moodle [50] [63]. Hence, the comparative usability of the two LMSs is discussed here.

Both Black Board and Moodle promote collaboration, critical reflection, group work, and communication. Literature survey suggests that both LMSs have the tools to create groups and assign students to each group manually. Both systems provide the communication tools through which participants can email to their peers, the whole class, their groups, or only the faculty. Individual and collective sharing of documents is possible in both the LMSs which kept a history of the changes. Both systems have a chat area for communication with tools for moderation. However, another study [32] has suggested that Moodle is as effective as Black Board. In fact, the researchers conclude that "in almost every module or function ..., Moodle was favored by course participants over Blackboard with the exception of the Discussion Board module ..." [64] (p. 77). One important difference between Blackboard and Moodle is the available course format/layout. Blackboard has a compartmentalised presentation that is standard and cannot be changed. In Moodle, there are three different formats: weekly, topics, or social. Research has shown [64], when the two systems were compared in terms of course format/layout, it was found that users favoured Moodle over BlackBoard.

One added advantage in Moodle system is that users can write mathematical formulas in Tex notation. On the other hand, there are problems associated with the writing of mathematical Equation in the Blackboard software platform [65], [66]. Further, Moodle is open source, meaning, it can be customised according to local needs and it is free of any license cost. On the contrary, Blackboard is expensive as it has procurement cost and requires payment of the subscription license [66]. However, it is true that open source software is only for IT experts and ordinary users find it difficult to install and use; above 66\% Moodle users are teachers, e-learning learning researchers or administrators of educational institutions [49].

Blackboard has a competitive edge over Moodle, in that it is very intuitive. Because of its e-collaborative learning tools, learning becomes social and participatory Downes [53], e-collaborative learning provides "learners with the opportunity of social interaction and participation ... for continuous learning based on technology and modern means of communication" [43]. The effectiveness of e-collaborative learning in promoting knowledge and skills has been evidenced by several studies. For instance, researches have [61] has emphasised the effectiveness of e-collaborative learning. 
Another study [67], e-collaborative learning provides a platform for learners to interact with each other, which requires instructors to motivate learners and plan well ahead for their academic courses and teaching methods. This direct interactive participation helps learners build knowledge and new skills and provides them with the opportunity to voice their inquiries and learn from each other. Therefore, blackboard promotes constructivist, interactive online learning environments [14] [15].

\section{Conclusions}

Global e-learning market is experiencing growth with e-Learning being increasingly used to facilitate talent management. According to Product and Users, the LMS market is expected to experience a growth of $23.17 \%$ between 2017 and 2018 [52].

In conclusion, it appears that Blackboard is a useful LMS that promotes pedagogical gain and constructivist perspectives. Blackboard provides collaborative and user-friendly environment for teaching-learning in terms of communication, assessment, and over all information management system. Thus, constructivists call for conducive e-learning environments that represent Blackboard system [68] that has the capacity to improve learning outcome [14]. Knowledge construction occurs through more interactive experiences as richer media tools are there in Blackboard environment. It is also evident that higher interactivity can lead to higher learner engagement that in turn impacts positively on better learning outcome and pedagogical gain [69]. However, absence of incentives such as training, financial rewards, positive attitudes and behaviours are factors that limit the use of e-learning technology [57] [62]. Thus, training is an important factor to facilitate maximum utilisation of Blackboard in terms of enhanced knowledge, skills and attitudes. Training motivates students to engage in an innovative way of learning through interaction and collaboration. Also, training serves to develop and implement technology that improves every aspect of educational technology.

The article advances that advantages of the Blackboard system are numerous. It offers access to a diverse means of didactic presentation and provides teachers with innovative ways of presenting knowledge. Blackboard is also a means for creation of motivational environments for learning.

\section{Conflicts of Interest}

The author declares no conflicts of interest regarding the publication of this paper.

\section{References}

[1] Meredith, S. and Newton, B. (2003) Methods of E-Learning: Technology Promise vs. Learner Needs Literature Review. International Journal of Management Education, 3, 43-56. https://doi.org/10.3794/ijme.33.73

[2] Mayes, J.T. (1995) Learning Technology and Groundhog Day. In: Strang, W., 
Simpson, V.B. and Slater, J., Eds., Hypermedia at Work: Practice and Theory in Higher Education, University of Kent Press, Canterbury.

[3] Davis, J., Lennox, S., Walker, S. and Walsh, K. (2007) Exploring Staff Perceptions: Early Childhood Teacher Educators Examine Online Teaching and Learning Challenges and Dilemmas. International Journal for the Scholarship of Teaching and Learning, 1, 1-15. https://doi.org/10.20429/ijsotl.2007.010208

[4] Norton, P. and Hathaway, D. (2008) Exploring Two Teacher Education Online Learning Designs: A Classroom of One or Many? Journal of Research on Technology in Education, 40, 475-495. https://doi.org/10.1080/15391523.2008.10782517

[5] Herrington, J., Reeves, T. and Oliver, R. (2005) Online Learning as Information Delivery: Digital Myopia. Journal of Interactive Learning Research, 16, 353-367.

[6] Rogerson-Revell, P. (2007) Directions in E-Learning Tools and Technologies and Their Relevance to Online Distance Language Education. Open Learning. The Journal of Open and Distance Learning, 22, 57-74. https://doi.org/10.1080/02680510601100168

[7] Moeller, B. and Reitzes, T. (2011) Integrating Technology with Student-Centered Learning. Education Development Center, Inc. (EDC), Quincy, MA. Nellie Mae Education Foundation.

[8] Olson, D.R. and Bruner, J.S. (1974) Learning through Experience and Learning through Media. In: Olson, D.R., Ed., Media and Symbols. The Forms of Expression, Communication, and Education, National Society for the Study of Education, Chicago, IL, 125-150.

[9] Miller, T.W. (2000) Marketing Research and the Information Industry. CASRO Journal, 2000, 21-26.

[10] Mioduser, D., Nachmias, R., Oren, A. and Lahav, O. (1999) Web-Based Learning Environments: Current States and Emerging Trends. In: Collis, B. and Oliver, R., Eds., Ed-Media 1999: World Conference on Educational Multimedia, Hypermedia and Telecommunications, Association for the Advancement of Computers in Education, Seattle, WA, 753-758.

[11] Mioduser, D., Nachmias, R., Oren, A. and Lahav, O. (1999) Web-Based Learning Environments (WBLE): Current Implementations and Evolving Trends. Journal of Network and Computer Applications, 22, 233-247. https://doi.org/10.1006/jnca.1999.0093

[12] Cairncross, S. and Mannion, M. (2001) Interactive Multimedia and Learning: Realizing the Benefits. Innovations in Education and Teaching International, 38, 156-164. https://doi.org/10.1080/14703290110035428

[13] Herrington, J., Oliver, R. and Reeves, T.C. (2006) Authentic Tasks Online: A Synergy among Learner, Task and Technology. Distance Education, 27, 233-248. https://doi.org/10.1080/01587910600789639

[14] Liaw, S.-S. (2008) Investigating Students' Perceived Satisfaction, Behavioural Intention, and Effectiveness of E-Learning: A Case Study of the Blackboard System. Computers and Education, 51, 864-873. https://doi.org/10.1016/j.compedu.2007.09.005

[15] Vovidesa, Y., Sanchez-Alonso, S., Mitropoulou, V. and Nickmans, G. (2007) The Use of E-Learning Course Management Systems to Support Learning Strategies and to Improve Self-Regulated Learning. Educational Research Review, 2, 64-74. https://doi.org/10.1016/j.edurev.2007.02.004

[16] Lajoie, S.P. and Azevedo, R. (2006) Teaching and Learning in Technology-Rich En- 
vironments. In: Alexander, P.A. and Winne, P.H., Eds., Handbook of Educational Psychology, Erlbaum, Mahwah, 803-821.

[17] Lajoie, S.P. (2005) Cognitive Tool for the Mind: The Promises of Technology: Cognitive Amplifiers or Bionic Prosthetics? In: Sternberg, R.J. and Preiss, D., Eds., Intelligence and Technology. Impact of Tools on the Nature and Development of Human Skills, Erlbaum, Mahwah, 87-102.

[18] Azevedo, R. and Hadwin, A.F. (2005) Scaffolding Self-Regulated Learning and Metacognition: Implications for the Design of Computer-Based Scaffolds. Instructional Science, 33, 367-379. https://doi.org/10.1007/s11251-005-1272-9

[19] Chang, M. (2007) Enhancing Web-Based Language Learning through Self-Monitoring. Journal of Computer Assisted Learning, 23, 187-196. https://doi.org/10.1111/j.1365-2729.2006.00203.x

[20] McMahon, M. (2002) Designing an On-Line Environment to Scaffold Self-Regulation. Annual Meeting of the Higher Education Research and Development Society of Australasia, Perth.

[21] Boekaerts, M. (1997) Self-Regulated Learning: A New Concept Embraced by Researchers, Policy Makers, Educators, Teachers, and Students. Learning and Instruction, 7, 161-186. https://doi.org/10.1016/S0959-4752(96)00015-1

[22] Bradford, P., Porciello, M., Balkon, N. and Backus, D. (2006-2007) The Blackboard Learning System: The Be All and End All in Educational Instruction? Journal of Educational Technology Systems, 35, 301-314. https://doi.org/10.2190/X137-X73L-5261-5656

[23] Carvendale, D. (2003) Study of Wisconsin Professors Finds Drawbacks to Course-Management Systems. Chronicle of Higher Education, 49, A26.

[24] Anderson, J.W. (2003) Faculty Perspectives of the Blackboard Course Delivery System.

[25] Morgan, G. (2003) Faculty Use of Course Management Systems. http://www.educause.edu/ir/library/pdf/ecar_so/ers/ers0302/ekf0302.pdf

[26] Prescott, D. (2013) Faculty Use of the Course Management System iLearn at the American University of Sharjah. Learning and Teaching in Higher Education: Gulf Perspectives, 10, 1-12. http://lthe.zu.ac.ae/index.php/lthehome

[27] Lane, L.M. (2008) Toolbox or Trap? Course Management Systems and Pedagogy. EDUCAUSE Quarterly, 31, 4-6.

[28] Blin, F. and Munro, M. (2008) Why Hasn't Technology Disrupted Academics' Teaching Practices? Understanding Resistance to Change through the Lens of Activity Theory. Computers and Education, 50, 475-490. https://doi.org/10.1016/j.compedu.2007.09.017

[29] Wingard, R.G. (2004) Classroom Teaching Changes in Web-Enhanced Courses: A Multi-Institutional Study. EDUCAUSE Quarterly, 27, 26-35.

[30] Al-Busaidi, K. (2009) The Impact of Learning Management System Characteristics and User Characteristics on the Acceptance of e-Learning. International Journal of Global Management Studies, 1, 75-91.

[31] Missula, S. (2008) Staff Perceptions of Blackboard as an Online Teaching Tool in Tertiary Education. Unpublished PhD Thesis, Unitec, Auckland.

[32] Zhang, D., Zhao, J., Zhou, L. and Numamaker, J. (2004) Can e-Learning Replace Classroom Learning? Communication of the ACM, 47, 75-78.

https://doi.org/10.1145/986213.986216 
[33] Gallagher, J. (2001) E-Learning Success Depends on Employee's Role. Insurance and Technology, 26, 55-57.

[34] Daugherty, M. and Funke, B. (1998) University Faculty and Student Perceptions of Web-Based Instruction. Journal of Distance Education, 13, 21-39.

[35] Wheeler, B. and Jarboe, G. (2001) New Poll Shows Faculty Prefer Web-Enhanced Courses to Either Classroom-Only or Distance-Only Courses: Student Learning Maximized with Web-Enhanced Classroom Instruction; Online-Only Rivals Classroom Only Instruction. http://www.webct.com/service/ViewContent?contentID=3522772

[36] Eldridge, B.A. (2014) Exploring Faculty Adoption and Utilization of Blackboard at a Community College in the Kentucky Community and Technical College System. Unpublished PhD Thesis, University of Kentucky, Kentucky.

[37] Nanayakkara, C. (2007) A Model of User Acceptance of Learning Management Systems: A Study within Tertiary Institutions in New Zealand.

[38] Graham, C., Cagiltay, K., Lim, B., Craner, J. and Duffy, T.M. (2001) Seven Principles of Effective Teaching: A Practical Lens for Evaluating Online Courses. http://technologysource.org/article/seven_principles_of_effective_teaching/

[39] Lee, Y. and Choi, Y. (2011) A Review of Online Course Dropout Research: Implications for Practice and Future Research. Educational Technology Research and Development, 59, 593-618. https://doi.org/10.1007/s11423-010-9177-y

[40] Davis, E.A., Hodgson, Y. and Macaualy, J.O. (2012) Engagement of Students with Lectures in Biochemistry and Pharmacology. Biochemistry and Molecular Biology Education, 40, 300-309. https://doi.org/10.1002/bmb.20627

[41] Leeds, E., Campbell, S., Baker, H., Radwan, A., Brawley, D. and Crisp, J. (2013) The Impact of Student Retention Strategies: An Empirical Study. International Journal of Management in Education, 7, 22-43. https://doi.org/10.1504/IJMIE.2013.050812

[42] Al-Hadrami, A. (2012) Factors That Affect Learners' Performance in Web-Based Courses: The Case of the Accounting Courses at the Hashemite University. Unpublished PhD Thesis, Coventry University, Coventry.

[43] Alzahrani, M.M. and Aljraiwi, S.S. (2017) Effectiveness of Using Blackboard Collaborate Tools in Promoting Practical Skills among Students of the Foundation Year in e-Learning Course. British Journal of Education, 5, 19-53.

[44] Belanger, Y. (2004) Summary of Fall 2003 Blackboard Survey Results.

[45] Brett, J., Landry, L., Griffeth, R. and Hartman, S. (2006) Measuring Student Perceptions of Blackboard Using the Technology Acceptance Model, Decision Sciences. Journal of Innovative Education, 4, 87-99. https://doi.org/10.1111/j.1540-4609.2006.00103.x

[46] Burrell-Ihlow, M. (2009) An Investigation of Teaching and Learning: Using Course Management Software (CMS) in a Typically Face to Face Course. International Journal on E-Learning, 8, 5-16.

[47] Chavan, A. and Pavri, S. (2004) Open-Source Learning Management with Moodle. Linux Journal, 2004, 2-4.

[48] Chen, D.-T., Wang, Y.-M. and Hung, D. (2009) A Journey on Refining Rules for Online Discussion: Implications for the Design of Learning Management Systems. Journal of Interactive Learning Research, 20, 157-173.

[49] Davis, F. (1993) User Acceptance of Information Technology: System Characteristics, User Perceptions and Behavioral Impacts. International Journal of Man-Machine 
Studies, 38, 475-487. https://doi.org/10.1006/imms.1993.1022

[50] Downes, S. (2005) E-Learning 2.0. http://www.downes.ca/post/31741

[51] Ismael, S.A. (2007) Using the Blackboard in Improving the Quality of e-Learning in Arab Universities: Qatar University Is an Example. 14th International Conference for Quality in Education and Training (Higher Education, Research and Challenges of the Knowledge Society), Casablanca, 15-22.

[52] Jackowski, M.B. and Akroyd, D. (2010) Technology Usage among Community College Faculty. Community College Journal of Research and Practice, 34, 624-644. https://doi.org/10.1080/10668920701831530

[53] Johnson, P. (2003) Top 10 Reasons Faculty Fail when Using Blackboard CMS. http://www.micsymposium.org/mics_2003/Johnson.PDF

[54] Kelly, T. and Bauer, D. (2004) Managing Intellectual Capital via E-Learning at Cisco. In: Holsapple, C., Ed., Handbook on Knowledge Management 2: Knowledge Directions, Springer, Berlin, 511-532.

[55] Krebs, M., Ludwig, M. and Müller, W. (2010) Learning Mathematics Using a Wiki. Social and Behavioral Sciences, 2, 1469-1476. https://doi.org/10.1016/j.sbspro.2010.03.220

[56] Labib, D.M. (2007) The Effectiveness of Using an Electronic Strategy for Collaborative Learning in the Computer Problems Course on the Cognitive and Knowledge Achievement among Students of the General Diploma. Unpublished PhD Thesis, Cairo University, Cairo.

[57] Lee, J., Cerreto, F.A. and Lee, J. (2010) Theory of Planned Behavior and Teachers' Decisions Regarding Use of Educational Technology. Educational Technology and Society, 13, 152-164.

[58] Machado, M. and Tao, E. (2007) Blackboard vs. Moodle: Comparing User Experience of Learning Management Systems. 37 th ASEE/IEEE Frontiers in Education Conference, Milwaukee, 33-38.

[59] Moodle (2017) Using TeX Notation. https://docs.moodle.org/33/en/Using_TeX_Notation

[60] Nayak, M.K. and Suesaowaluk, P. (2007) Advantages and Disadvantages of E-Learning Management System. 4th International Conference One Learning for Knowledge-Based Society, Bangkok, 101-111.

[61] Northrup, P. (2001) A Framework for Designing Interactivity into Web-Based Instruction. Educational Technology, 41, 31-39.

[62] Parisio, M.L. (2011) Engaging Students in Learning through Online Discussion: A Phenomenographic Study. In: Williams, G., Statham, P., Brown, N. and Cleland, B., Eds., Changing Demands, Changing Directions, the University of Tasmania, Hobart, 989-993.

https://www.ascilite.org/conferences/hobart11/downloads/ProceedingsV3.pdf

[63] Parker, K.R. and Chao, J.T. (2007) Wiki as a Teaching Tool. Interdisciplinary Journal of Knowledge and Learning Objects, 3, 57-72. https://doi.org/10.28945/3131

[64] Rodchua, S. (2004) The Measurement of Quality and Practices of Internet-Based Distance Learning Regarding Students' Perception in the Industrial Management Program. Unpublished Dissertation, Central Missouri State University, Warrensburg.

[65] Siew-Eng, L., Mahdi, R., Kim-Leong, L., Chee-Khium, C. and Siew-Ching, L. (2012) Exploring Net Meeting Characteristics for Online Teaching and Learning Mathe- 
matics. http://ipedr.com/vol37/013-ICMEI2012-E00031.pdf

[66] Strijbos, J.W., Kirschner, P. and Martens, R. (2004) What We Know about CSCL and Implementing It in Higher Education. Kluwer Academic Publishers, Dordrecht.

[67] Storey, M.A., Phillips, B., Maczewski, M. and Wang, M. (2002) Evaluating the Usability of Web-Based Learning Tools. Educational Technology and Society, 5, 91-100.

[68] Taber, K. (2011) Constructivism as Educational Theory: Contingency in Learning, and Optimally Guided Instruction. Nova Science Publishers Inc., 39-61.

[69] Tonsmann, G. (2014) A Study of the Effectiveness of Blackboard Collaborate for Conducting Synchronous Courses at Multiple Locations. In Sight: A Journal of Scholarly Teaching, 9, 54-63. 